\title{
Promoting physical activity through video games based on self-behavioral models
}

\section{Promoção da atividade física através de videojogos baseados em modelos de autorregulação comportamental}

\author{
M. Abreu ${ }^{1}$, I. Neves ${ }^{1}$, J. Silva ${ }^{1}$, O. Santos ${ }^{2,3}$ \\ ${ }^{1}$ Psychology Department, University of Évora, PORTUGAL \\ ${ }^{2}$ CBIOS, Faculdade de Ciências e Tecnologias da Saúde, Universidade Lusófona, Campo Grande 376, 1649-024 Lisboa, \\ PORTUGAL \\ ${ }^{3}$ ONOCO. Portuguese Obesety and Weight Control Observatory, Lisbon, PORTUGAL \\ Email: marta_if_abreu@hotmail.com
}

\begin{abstract}
Physical activity is an essential component of a healthy lifestyle, promoting health and preventing various chronic diseases. Despite this evidence, it is known that the younger generations invest much time in sedentary activities such as television viewing, videogames or reading, which potentially can lead to an increase in the prevalence of sedentary behaviors in adulthood. These behaviors have been identified as factors of disturbance in the balance between intake and energy expenditure, contributing to the increasing number of overweight and obese people and, further downstream, the prevalence of cardiovascular diseases and cancer (among others). The emergence of the Exergames (videogames that involve physical activity, either light, moderate or intense) and games whose narrative alters pathogenic beliefs, contrary to the potential risk effect of gaming, by combining the playful context of videogames with physical activity (mild to intense). This study discusses some salutogenic principles of a new generation of videogames where virtual and real come together, ipromoting salutogenic behavioral patterns, namely through greater energy expenditure. The ideas are based on theoretical and empirical contributions from health psychology, in addition to the potential of computer technology applicable to traditional videogames and Exergames
\end{abstract}

Keywords: Videogames, sedentary behaviors, obesity, physical activity, self-regulation.

\section{Resumo}

A atividade física é uma componente essencial de um estilo de vida promotor de saúde e com potencial de prevenção para diversas doenças crónicas. Apesar desta evidência, é sabido que as gerações mais novas investem muito tempo em atividades sedentárias, como o visionamento de televisão, a prática de videojogos ou a leitura, com potencial aumento de prevalência de comportamentos sedentários na vida adulta. Estes comportamentos têm sido identificados como fatores de perturbação no balanço entre aporte e dispêndio energético, contribuindo para o aumento da prevalência do excesso de peso e da obesidade e, mais a jusante, da prevalência de doenças cardiovascular e oncológica (entre outras). A emergência dos exergames (videojogos que implicam atividade física, de ligeira a intensa) e de jogos cuja narrativa permita a alteração de crenças patogénicas, contraria o efeito potencial de risco dos videojogos, ao combinar o contexto lúdico dos videojogos à atividade física. Com base em contributos teóricos e empíricos da psicologia da saúde, e recorrendo às potencialidades informáticas aplicáveis aos videojogos tradicionais e aos exergames, fundamentam-se neste artigo alguns princípios salutogénicos de uma nova geração de videojogos, em que o virtual e o real se conjugam, na promoção de padrões comportamentais salutogénicos, nomeadamente através de maior gasto energético.

Palavras-Chave: Videojogos; Comportamentos sedentários; Obesidade; Atividade física; Auto-regulação. 


\section{Introduction}

There is much evidence on how regular physical activity benefits health and is associated with the prevention of morbidity and increasing life expectancy (1-3). Despite this evidence, sedentary behavior is very prevalent in developed countries, especially in Portugal (4). Technological developments, particularly in the area of digital entertainment equipment (TV and videogames), has been linked to a reduction in physical activity, particularly among youth $(2,5)$.

With the emergence of computers and gaming consoles, routines and traditional recreational activities among children and adolescents (including those performed on the street with colleagues and friends), which promote physical activity, have been deprecated in favor of the more sedentary (and often more solitary) activity of multimedia games, where physical action is delegated to the characters of videogames, controlled by very low energy-expenditure movements. The multimedia features and recreational activities associated with the challenge of skills training (e.g. fine motor and/or cognition), facilitate adherence to these games at all stages of the life cycle, including in childhood.

Children and young people adhere to (video)games which are becoming increasingly sophisticated and able to create scenarios very similar to our own reality (5). A Marktest study (6), shows that three in four young people aged 15 to 17 years have a habit of regularly (daily) playing on the computer or console. According to data from recent studies on the prevalence of obesity in children and adolescents (4), those who spent more than two hours in the practice of sedentary activities (e.g. watching TV, playing videogames and spending time on the computer) are mostly male, older, their parents/carers have an education level of less than nine years and their residential area is considered as dangerous, compared to subjects who spent less than two hours carrying out these activities. In addition, the time spent watching television is associated with increased body mass index (4).

In Portugal, it has been found that the body mass index of youngsters increases with time spent playing videogames (with both boys and girls) (7). The same has been seen in other studies: the gradual replacement of traditional physical activities by practice of videogames (sedentary) is associated with a more sedentary lifestyle and thus increases the risk of obesity and associated morbidities $(8,9)$. The fact that this sedentary habit is formed during childhood and adolescence becomes more relevant in the current context, in which juvenile obesity is assuming global endemic proportions, and

\section{Introdução}

Existe muita evidência em como a atividade física regular traz benefício para a saúde e se associa à prevenção de morbilidade e ao aumento de esperança de vida (1-3). Apesar desta evidência, o comportamento sedentário é muito prevalente nos países desenvolvidos, nomeadamente em Portugal (4).

A evolução tecnológica, nomeadamente na área dos equipamentos digitais de lazer (televisão e videojogos), tem sido associada ao desencorajar da prática do atividade física, nomeadamente entre jovens $(2,5)$.

Com a emergência dos computadores e das consolas de jogos, as rotinas e as atividades lúdicas tradicionais entre crianças e adolescentes (incluindo as realizadas na rua com colegas e amigos), promotoras de atividade física, têm sido preteridas em favor da atividade, mais sedentária (e muitas vezes, mais solitária) de jogos multimédia, em que a ação física é delegada para os personagens dos videojogos, controlados por movimentos de muito baixo dispêndio energético. As características multimédia e lúdicas, associadas ao desafio de treino de competências (por ex..$^{\circ}$, de motricidade fina e/ou de cognição), facilitam a adesão a estes jogos em todas as fases do ciclo de vida, incluindo idades infantis.

As crianças e os jovens aderem a (vídeo)jogos cada vez mais sofisticados e capazes de criar cenários muito semelhantes à própria realidade (5). Um estudo da Marktest (6), mostra que, três em cada quatro jovens dos 15 aos 17 anos têm por hábito regulares (diários) o jogar computador ou consola. De acordo com dados dos últimos estudos de prevalência da obesidade em crianças e adolescentes (4) aqueles que despendem mais de duas horas na prática de atividades sedentárias (ex.: ver televisão, jogar videojogos e passar tempo no computador) são maioritariamente do sexo masculino, mais velhos e os seus pais/cuidadores têm um nível de escolaridade inferior a nove anos e consideram que a sua área de residência é perigosa, comparado com os sujeitos que despendem menos de duas horas na prática dessas atividades. Para além disto, o tempo investido a ver televisão está associado com o aumento do índice de massa corporal (4).

Em Portugal, foi observado que o índice de massa corporal dos jovens aumenta com o tempo dedicado com videojogos (quer nos rapazes quer nas raparigas) (7). O mesmo tem sido verificado noutros estudos: a progressiva substituição das atividades físicas tradicionais pela prática de videojogos (sedentários) está associada a um estilo de vida mais sedentário e, desta forma, ao aumento de risco de obesidade e morbilidades associadas $(8,9)$. $\mathrm{O}$ facto de este hábito sedentário ser formado durante a infância e adolescência torna-se mais relevante no contexto atual, em que a obesidade infanto-juvenil assume proporções endémicas a nível mundial, e porque o excesso de peso em crianças e adolescentes tende a persistir (e a agravar-se) na idade adulta (10). 
because the weight excess in children and adolescents tends to persist (and became worse) in adulthood (10). The most recent national-based study about adult obesity refers to data collected between January 2003 and January 2005 (8 116 subjects aged 18-64 years) and found that $53.6 \%$ of participants are overweight (preobesity and obesity included) (11)requiring serious public health attention. The first Portuguese nationwide representative survey about obesity (with objective anthropometric measurement. Among young people from 11 to 15 years (the most recent data, collected between 2008 and 2009), the corresponding prevalence of people overweight is $33.9 \%$ (according to WHO criteria) (7).

In this context, there is increasing interest in promoting physical activity by converting typically sedentary behaviors into physical activity $(2,12)$. Although the promotion of physical activity, in addition to the fun associated with videogames, is a bet of obvious importance, there is also a tendency to join what is perceived as pleasing to the useful: in other words, the potential of using the playful and intrinsic motivation (13) surrounding videogames in order to promote positive attitudes towards physical activity and even the production of physical activity. Nowadays, technological resources facilitate the link between videogames and health in that the motor components promote greater energy expenditure than would normally be associated with simple control of the game through the fingers and hands. There is an emerging technology with great potential to overcome many of the barriers to physical activity associated with traditional videogames (14): the Exergames (video games that involve light, moderate or even intense physical activity), through consoles like Wii ${ }^{\circledR}$ or PlayStation ${ }^{\circledR}$. This type of videogame is being increasingly used in implementing programs of physical activity and healthier lifestyles, targeting people of all ages (2). Still, the players "stay at home". That is, these games, despite encouraging allowing greater energy expenditure, tend to involve less contact with the world outside of the home. Therefore, they also tend to promote greater social isolation because they reduce the amount of team games played with peers. Current technology enables us to integrate tools that combine traditional practices with electronic games. These are preferably collective and support physical activity, moderate to intense in a collective context (combining a health behavioral style with promotion of social interaction among young people). In order for this combination of positive factors to become possible, we need to take into account what research has revealed about the advantages and disadvantages of classic vid-
O estudo de base nacional mais recente sobre obesidade no adulto refere-se a dados recolhidos entre Janeiro de 2003 e Janeiro de 2005 (8116 sujeitos com idades compreendidas entre os 18-64 anos) e revelou que 53,6\% dos participantes tem excesso de peso (pré-obesidade e obesidade incluídas) (11).

Entre os jovens dos 11 aos 15 anos (dados mais recentes, recolhidos entre 2008 e 2009) a prevalência correspondente é de 33,9\% (segundo os critérios da OMS) (7).

Neste contexto, o interesse em promover a atividade física através da conversão de comportamentos tipicamente sedentários em atividades físicas tem sido crescente $(2,12)$. Embora a promoção de atividade física em complemento da diversão associada a videojogos seja uma aposta de importância evidente, verifica-se também uma tendência de juntar o percepcionado como agradável ao útil: ou seja, de utilizar o potencial lúdico e de motivação intrínseca (13) dos videojogos à promoção de atitudes favoráveis à prática de atividade física e mesmo à produção de atividade física.

Este movimento de procurar associar os videojogos à saúde é hoje em dia facilitado pelos recursos tecnológicos, que permitem implicar componentes motores de maior dispêndio energético do que o associado ao simples controlo do jogo através dos dedos e mãos. Fala-se assim de uma tecnologia emergente com grande potencial para superar muitas das barreiras à atividade física associadas aos videojogos tradicionais (14): os exergames (videojogos que implicam atividade física leve, moderada ou mesmo intensa), como os possibilitados por consolas como o Wii ou a Playstation ${ }^{\circ}$. Este tipo de videojogo tem vindo a ser progressivamente mais utilizado em programas de implementação da atividade física e de estilos de vida mais saudáveis, dirigidos a populações de todas as idades (2). Ainda assim, os jogadores "permanecem em casa". Ou seja, estes jogos, apesar de permitirem maior gasto energético, tendem a implicar menor contacto com o mundo fora-de-casa e, em associação, tende a promover maior isolamento social, pela redução de jogos coletivos presenciais (com/entre pares).

Apesar deste facto, a tecnologia atual permite a integração de ferramentas que conjuguem jogos electrónicos com práticas tradicionais, de preferência coletivas, que sustentem a atividade física, de moderada a intensa, em contexto coletivo (aliando um estilo comportamental saudável à promoção da interação social entre jovens). Para que esta conjugação de virtudes seja possível, importa ter em conta o que a investigação tem revelado quanto às vantagens e desvantagens dos videojogos clássicos (mais "imobilizantes") para a saúde. Importa também que os videojogos integrem, na sua génese, alguns princípios baseados na autoregulação de comportamentos salutogénicos.

\section{Potenciais não salutogénicos dos videojogos}

Os videojogos são muitas vezes encarados como promotores de atividade pouco útil para o adequado desenvolvimento dos jovens, nomeadamente devido ao seu poder de sedução, 
eogames (more "immobilizing") for health. It is also important that some principles based on self-regulated salutogenic behavior are incorporated in their creation.

\section{Non-salutogenic potential of videogames}

Videogames are often regarded as promoters of activity with low utility for the proper development of young people, particularly due to their power of seduction, which competes with (or compromises) the investment in other leisure activities that have the potential for social learning and higher energy spending. The practical impact of videogames on reducing energy expenditure is also associated with the general context of easy access to hypercaloric food and the favoring of sedentary activities among young people: the increased scholarly/academic demands (implying increased daily time spent in a sitting position), ease of access to technology (less movement promoters) and reduction of green spaces in urban centers, among others (2).

Videogames are also characterized by a competitive environment, often promoting violence, and by psychomotor and emotional excitement (5). Several studies revealed that most violent games can lead to aggressive behavior and delinquency (15-17). In 2004 during an investigation with 8th and 9th grade young children, Gentile, Lynch, Linder and Walsh found that those who devoted much of their time to playing videogames were considered more hostile, argued more often with their teachers, were more likely to engage in physical fights and had poorer school performance (18)

Moreover, videogames integrate a new form of language and communication, promoting the establishment of "virtual friendship" relations. Through playing with "virtual friends", messages are exchanged and ideas are shared with peers without physical contact. The time devoted to these virtual friends tends to limit the time available for contact with "real friends", which inhibits the usual forms of sociability and leisure (5). Pereira and colleagues (2009), during a study with young people between 14 and 16 years old who regularly played computer games and traditional sports, advocate that young people value (in both activities) aspects such as socializing, recreation, competitive spirit and the fact that they learn (5).

Finally, the impact of excessive use of videogames and sedentary lifestyles is noted on physical health for the child is predisposed to the risk of obesity, as mentioned above, and its associated psychosocial problems (e.g. bullying, eating compulsions, decreased self-esteem, etc.) (19).

\section{Salutogenic potential of videogames}

The negative aspects that the literature highlights in que compete com (ou mesmo compromete) o investimento noutras atividades de lazer com potencial de aprendizagem social e de maior dispêndio energético. O impacto da prática de videojogos na redução do dispêndio energético associa-se ainda ao contexto geral de acesso fácil a alimentos hipercalóricos e de favorecimento de atividades sedentárias entre jovens: o aumento das exigências escolares/académicas (implicando incremento de tempo diário na posição de sentado), a facilidade de acesso às tecnologias (promotoras de menor movimentação) e redução dos espaços verdes nos grandes centros urbanos, entre outros (2).

Os videojogos caracterizam-se ainda por um ambiente competitivo, muitas vezes promotores de violência, e por excitação psicomotora e emocional (5). Diversos estudos realizados demonstram que os jogos mais violentos podem conduzir a comportamentos de agressividade e mesmo à delinquência (15-17). Gentile, Lynch, Linder e Walsh, em 2004 , numa investigação com jovens do $8^{\circ}$ e $9^{\circ}$ ano de escolaridade, verificaram que aqueles que dedicavam muito do seu tempo à prática de videojogos foram considerados mais hostis, discutiam mais frequentemente com os seus professores, tinham maiores probabilidades de se envolver em lutas físicas e apresentavam desempenho escolar mais baixo (18) Por outro lado, os videojogos integram novas formas de linguagem e de comunicação, promovendo o estabelecimento de relações de "amizade virtual". Joga-se com "amigos virtuais", trocam-se mensagens e partilham-se ideias com pares, sem contacto físico. O tempo dedicado a estes amigos virtuais tende a limitar o tempo disponível para contactos com "amigos reais", inibindo as habituais formas de sociabilidade e de lazer (5). Pereira e colaboradores (2009), num estudo com jovens entre os 14 anos e os 16 anos de idade, praticantes regulares de videojogos e de desportos tradicionais, advogam que os jovens valorizam, quer numa prática quer noutra, aspetos como a socialização, o lazer, o espírito competitivo e as aprendizagens que delas retiram (5).

Por fim, o impacto da utilização excessiva de videojogos e de estilos de vida sedentários faz-se notar na saúde física, predispondo a criança ao risco de obesidade, como já foi referido anteriormente, e problemas psicossociais associados (e.g., bullying, compulsões alimentares, diminuição da auto-estima, etc.) (19).

\section{Potenciais salutogénicos dos videojogos}

Os aspetos negativos que a literatura salienta como relacionados com a prática de videojogos não anulam alguns aspetos positivos que têm sido identificados na literatura científica.

De uma forma geral, os videojogos melhoram as competências espaciais e desenvolvem aptidões que podem ser transferidas para a vida escolar e pessoal. Os seus benefícios manifestam-se em aspetos cognitivos e psicomotores, na coordenação oculomotora e na organização espacial, bem como na melhoria da capacidade de atenção aos detalhes (5). Com estas novas tecnologias, os jovens aprendem sem se aperce- 
relation to the playing of videogames do not override some positive aspects that have been identified in the scientific literature.

In general, videogames improve spatial skills and develop skills that can be transferred to the school and personal lives. Their benefits are manifested in cognitive and psychomotor aspects, eye-motor coordination and spatial organization, as well as improving the capacity of attention to detail (5). With these new technologies, young people learn without realizing that they are learning (20). Written information, sound, music, animation, videos, photographs and images in three dimensions benefit learning, if well explored (2).

The emergence of exergaming (video games that involve light, moderate or even intense physical activity) is a good example of how the practice of video games can be used for the purpose of replacing sedentary behaviors with active behaviors, particularly in younger populations. This practice is associated with an energy expenditure similar to the traditional physical activities in light to moderate intensity (e.g. jogging, hiking, etc.), contributing to an increase daily physical activity, as found by Maddison et al (2007) in a study of children between 10 and 14 years old. These authors concluded that even just the movement of the upper torso in exergaming is a good alternative to periods of inactivity, especially among more sedentary children (2).

In this new generation of videogames, the human-computer interaction depends entirely on the player's body movement in front of a camera. The player interacts with the images on the screen, based on the activities proposed by the type of game - e.g. table tennis, jogging, aerobics, dance, football, among others (21). Replacing downtime with the use of active videogames for about 30 minutes per day can have a positive impact on energy expenditure, thus countering sedentary lifestyles (2).

On a therapeutic level, these kind of videogames have been used in pediatric rehabilitation $(22,23)$. For example, Wii ${ }^{\circledR}$ videogames have been used in the rehabilitation process, involving movements similar to those implemented in actual physical activities. The use of these games translates into opportunity for movement and high levels of motivation, which is fundamental to encourage children in situation of rehabilitation (22,23). Kato and Beale (2006) analyzed the acceptability among oncologic patients, regarding an action game as a tool for learning about the disease and to promote self-care during treatment. They concluded that using themes related to cancer in an action videogame could be a useful tool for nurses to improve their sense of understanding and self-care for adolescents and young adults with cancer (22). berem que estão a aprender (20). As informações escritas, o som, a música, a animação, os vídeos, as fotografias e as imagens em três dimensões são mais-valias para a aprendizagem, desde que bem exploradas (2).

A emergência dos exergames é um bom exemplo de como a prática de videojogos pode ser utilizada com o objetivo de substituição de comportamentos sedentários por comportamentos ativos, particularmente junto de populações mais novas. Esta prática encontrase associada a um gasto energético similar ao registado em atividades físicas tradicionais de intensidade leve a moderada (e.g.: jogging, caminhadas, entre outras), contribuindo, então, para o aumento da atividade física diária, tal como encontrado por Maddison et al (2007) num estudo com crianças entre os 10 e os 14 anos de idade. Estes autores concluíram que mesmo só a movimentação dos membros superiores do tronco nos exergaming é uma boa alternativa aos períodos de inatividade, principalmente junto das crianças mais sedentárias (2).

Nesta nova geração de videojogos, a interação jovem-computador depende inteiramente do movimento corporal do jogador diante de uma câmara, interagindo com imagens apresentadas no ecrã, com base em atividades propostas pelo tipo de jogo - e.g.: ténis de mesa, corrida, exercícios aeróbicos, dança, futebol, entre outros (21). Substituir períodos de inatividade pela utilização dos videojogos ativos durante aproximadamente 30 minutos por dia, pode ter um impacto positivo no gasto energético, contrariando estilos de vida sedentários (2).

A nível terapêutico, este tipo de videojogos têm sido utilizados na reabilitação pediátrica $(22,23)$. Por exemplo, os videojogos da consola Wii têm sido utilizados em processo reabilitativo, envolvendo movimentos similares aos executados nas atividades físicas reais. A utilização destes jogos traduz-se em oportunidade de movimentação e, por elevados níveis de motivação (fundamental na adesão por parte das crianças), à reabilitação $(22,23)$. Kato e Beale (2006) analisaram a receptividade, por parte de doentes com cancr, a um jogo de ação como ferramenta de aprendizagem a respeito da doença e promotora dos autocuidados durante o tratamento. Concluíram que um videojogo de ação com recurso a temas relacionados com o cancro poderia ser uma ferramenta útil para os enfermeiros no sentido de melhorar a compreensão e o auto-cuidado de pacientes (adolescentes e jovens adultos) com cancro (22).

Para indivíduos com deficiências físicas e cognitivas, as barreiras físicas, sociais e ambientais para a atividade física são determinantes major para o sedentarismo. Também nestes casos, o recurso aos exergames, apropriados às suas competências psicomotoras, permite ultrapassar essas barreiras, pelo que constituem oportunidades de treino de competências de motricidade e 
For individuals with physical and cognitive disabilities, physical barriers, social and environmental physical activity are major determinants of inactivity. Moreover, in these cases the use of exergames appropriate to their psychomotor skills, can allow them to overcome these barriers. The videogames therefore present opportunities for skills training and motor expansion and promotion of physical activity for this population (14).

Several studies $(21,24)$ support the use of exergames as promoters of change in feeding behavior. However, the effectiveness of interventions with exergames is not consensual.

Epstein and colleagues (2008) reported that the integration of exergaming alone in the treatment of obesity fails because it often does not yield the expected results. This is mainly due to the low levels of motivation and interest of the children and young people as they become familiar with the game $(12,25,26)$.

Radon et al. (2011) concluded that the use of active videogames was not enough to treat obesity in a group of 84 young people between 13 and 28 years old and found that the energetic cost associated with the practice of exergames study was lower than the energy expended in actual physical activities (26)

Finally, many of these games are not accessible to all socioeconomic and ethnic groups (in part because of their high cost). whilst others only promote exercise for the upper body and not the whole body (2).

Recent theoretical perspectives that should be taken into account when designing videogames which target salutogenic behaviors.

Taking into account some of the main positive and negative points of video gaming, it is important to reflect on what can and should be used to guide, on the one hand, the desired change in behavior and, on the other hand, the design and development of new videogames (27).

According to the Elaboration Likelihood Model (28) the story of the game needs to be credible, attractive and pleasant so that it has a persuasive effect on the target audience (24). For its part, the socio-cognitive theory of Bandura (29) values the creation of goals, modeling and development of skills throughout the game (24). Bandura argues that behavior change is a function of enhanced skills and confidence (self-efficacy) to use the new behavior, while modeling and feedback are the key to learning skills (27). Given these models and the self-determination theory of Deci and Ryan (2000), the video players must receive feedback throughout the game on their performance, and experience the pleasure associated with the overcoming of the game's difficul- de expansão e promoção da atividade física para estas populações (14).

Vários estudos $(21,24)$ sustentam a utilidade dos exergames como promotores da modificação do comportamento alimentar. Contudo, a efetividade das intervenções com exergames não é consensual. Epstein e colaboradores (2008) referem que a inserção dos exergaming, por si só, no tratamento da obesidade acaba, frequentemente, por não trazer os resultados esperados, sobretudo devido ao baixo interesse e à fraca motivação das crianças e jovens à medida que se vão familiarizando com o jogo $(12,25,26)$. Radon et al. (2011) concluíram que o recurso a videojogos ativos não foi suficiente para tratar a obesidade num grupo de 84 jovens entre os 13 anos e os 28 anos, tendo verificado que o gasto enérgico associado à prática dos exergames em estudo foi inferior à energia despendida em atividades físicas reais (26).

Por fim, muitos destes jogos não são acessíveis a todos os grupos étnicos ou socioeconómicos (muito em parte pelo seu ainda elevado custo), enquanto outros não promovem a exercitação de todo o corpo, mas apenas da parte superior do tronco (2).

Perspetivas teóricas recentes a considerar no design de videojogos promotores de comportamentos salutogénicos

Tendo em consideração alguns dos principais aspectos negativos e positivos dos videojogos, torna-se importante refletir sobre o que pode e deve ser utilizado para nortear, por um lado, a desejada mudança de comportamentos e, por outro lado, o design e o desenvolvimento de novos videojogos (27).

Segundo a Elaboration Likelihood Model (28) a história do jogo deverá ser credível, atrativa e agradável para que possa ter efeito de persuasão junto do respetivo público-alvo (24). Por seu lado, a Teoria Sociocognitiva de Bandura (29) valoriza a criação de objetivos, a modelagem e o desenvolvimento das capacidades ao longo do jogo (24). Bandura defende que a mudança de comportamento é uma função de competências e confiança reforçadas (auto-eficácia) em produzir o novo comportamento, sendo a modelagem e o feedback elementos-chave para a aprendizagem de competências (27). Atendendo a estes modelos e à teoria da auto-determinação de Deci e Ryan (2000), os vídeo-jogadores devem, ao longo do jogo, receber feedback sobre o seu desempenho e promover percepção de prazer no ultrapassar de dificuldades do jogo, que reforçam a satisfação de necessidades psicológicas fundamentais como a de competência (mestria), de autonomia (na forma de ultrapassar as dificuldades do jogo) e de relação (quer 
ties. These difficulties should reinforce the satisfaction of psychological needs such as competence, autonomy (as to how to overcome the difficulties of the game) and of relating to others (either with other players, even if at distance, or with game characters) $(13,24)$.

None of these approaches highlight the temporal factor, the critical decision making moment related to the practice of health behaviors. While most health behaviors have few immediate benefits and cause discomfort and embarrassment at the time of conduct, maladaptive behaviors tend to have the opposite self-regulation characteristic (30). In other words, pathogenic behaviors tend to have perceived benefits in the short term, whereas the substantial costs tend to be perceived later on. When performing these behaviors, the individual has no perception of the harm they may cause because it is not visible at the moment of action. For example, regular physical activity is associated with many benefits, both for health and for the physical appearance, and it even has psychological benefits. However, none of these benefits are manifested at the time of the decision to wake up in time before going to school or to work and do physical activity; what is perceived as more important, then, is the inconvenience of getting up earlier. There is, therefore, a differential effect of timing of the perceived costs and benefits, in decision-making (30). In a seminal article which presents the Temporal SelfRegulation Theory (2007), Hall and Fong argue that the ability to practice a behavior over time is a combination of complex dynamics between biological, cognitive and social aspects.

According to this theory, behavioral intentions are determined by beliefs about future behaviors expectations (as well as other health beliefs), associated with temporal valuations of costs and benefits. The realization of these intentions into effective behaviors depends on the behavioral history (in other words, the contingent associations between stimuli and responses), and self-regulatory capacity. This includes the executive system of the individual's neuroanatomical and neurofunctional capacity. Thus, the gap between intention and behavior is moderated by (a) bullying behavior, defined as the probability of performing a particular behavior in terms of habit leading to action and (b) the capacity for selfregulation, in other words, the internal capacity that the individual has to guide and regulate their own behavior (30).

Given the assumptions made in this self-regulation theory, the new generation of videogames must incorporate functional elements, narrative and design to influence the motivational sphere of the individual to practice regular exercise. This includes: com outros jogadores, mesmo que à distância, quer com personagens do jogo $)(13,24)$.

Nenhuma destas abordagens teóricas destaca o fator temporal, fundamental no momento da tomada de decisão para a prática de comportamentos de saúde. A este nível, enquanto a maioria dos comportamentos de saúde tem poucos benefícios imediatos (causando até algum desconforto e embaraço na altura de os realizar) os comportamentos desadaptativos tendem a apresentar a característica de autorregulação oposta (30): tendem a apresentar benefícios percepcionáveis a curto prazo e os custos substanciais apenas se tornam salientes mais tarde. Por exemplo, a atividade física regular é associada a muitos benefícios, tanto de saúde, como de aparência física e até mesmo a benefícios psicológicos. No entanto, nenhum destes benefícios se manifesta na altura da decisão de acordar atempadamente para, antes de ir para a escola ou para o trabalho, praticar exercício; o que é percepcionado como mais importante, nessa altura, é o inconveniente de levantar cedo. Há assim um efeito diferencial da temporalidade dos custos e dos benefícios percepcionados, aquando da tomada de decisão (30).

Num artigo seminal, em que é apresentado o Modelo de Auto-Regulação Temporal (2007), Hall e Fong defendem que a capacidade de se praticar um comportamento ao longo do tempo surge de uma combinação dinâmica complexa entre fatores biológicos, cognitivos e sociais.

De acordo com este modelo, as crenças quanto a expectativas de resultados dos comportamentos (bem como outras crenças de saúde), associadas a valorizações temporais de custos e benefícios, determinam as intenções comportamentais. As concretizações destas intenções em comportamentos efetivos dependem da história comportamental (dito de outra forma, das associações contingenciais entre estímulos e respostas), e da capacidade autorregulatória, incluindo os seus correlatos neuroanatómicos e neurofuncionais, do sistema executivo do indivíduo. Assim, a relação entre intenção e comportamento é moderado pela (a) prepotência comportamental, definida como a probabilidade de desempenhar um determinado comportamento em função do hábito face a pistas para a ação e (b) pela capacidade de auto-regulação, ou seja, a capacidade interna que o individuo tem de orientar e regular os seus comportamentos (30).

Tendo em conta os pressupostos defendidos neste modelo de autorregulação, é necessário que a nova geração de videojogos integre elementos funcionais, narrativos e de design que influencie a esfera motivacional do indivíduo para a prática do exercício físico regular, nomeadamente:

Que corresponda, em termos gráficos, de dinâmica do jogo, e de narrativa associada ao jogo, aos padrões atuais da indústria dos videojogos, presentes em jogos tipicamente mais sedentários; 
- Meeting the current standards of the gaming industry in terms of the dynamics and narrative that are typical in the more sedentary games;

- Relating the goals of the game to health goals;

- Providing feedback quickly, both on the player's performance in relation to the goals of the game, and also in relation to the health gains (e.g. the number of calories lost in an activity);

- Giving hints as to how to perform the proposed activities, activities that are appropriate to the age of the individual and with which they are already familiar (jumping, running, etc.), so that they can develop the necessary autonomy to guide their own behavior.

These principles, if well articulated, promote the intention-behavior link, which helps the individual to perceive more clearly the benefits of their behavior and to want to extend it in the long term, in a playful and therefore intrinsically motivating context (13).

\section{A New Generation of VideoGames: RealVirtua Games}

According to the advantages and disadvantages presented by videogames and research performed in this field, it is possible to recommend how they might be beneficially used (when time is limited, to promote health through physical activity) among young people to encourage regular physical activity.

According to the principles of videogame development, in order to achieve health benefits through the promotion of physical activity, it is important to develop games that combine classic elements of traditional videogames with elements of the real space/world. This proposal results in what can be called by RealVirtua Games.

The RealVirtua Games would be intended mainly for young people aged around 13 years old (without any development pathology), since this is a stage of development in which autonomy is formed. At this stage of autonomy and identity construction, these young people emphasize the fact that "non-constant" parental supervision, although they can (and, in our view, should) also interact and participate in the game, without exerting "control" over their learners.

As the name suggests, this new generation of videogames would have two dimensions:

1. Virtual dimension. Taking into account the theories described previously, namely the Elaboration Likelihood Model (28), the game should have a believable and enjoyable story to captivate the players more easily (24). Furthermore, it is important that the story presents a common thread, which is dynamic, credible and attractive, so as to promote fun and concentration, as well as fantasy and enthusiasm, which intrinsically motivate the players (27).
- Que associe objetivos do jogo a objetivos de saúde; - Que devolva informação (feedback) de forma rápida, não só sobre o desempenho do jogador relativamente aos objetivos do jogo, mas também relativamente aos ganhos de saúde (por exemplo, número de calorias perdidas numa atividade);

- Que dê pistas para realizar as atividades propostas, atividades estas adequadas à idade do individuo e com as quais este já esteja familiarizado (saltar, correr, entre outras), para que desenvolva a autonomia necessária para orientar os seus próprios comportamentos.

Estes princípios, se bem articulados, promovem a ligação intenção-comportamento, o que leva o indivíduo a percecionar com mais clareza os benefícios do seu comportamento e a querer prolongá-lo a longo prazo, num contexto lúdico e, portanto, intrinsecamente motivador (13).

\section{Uma Nova Geração de Videojogos: RealVirtua Games}

Tendo em conta as vantagens/desvantagens apresentadas pelos videojogos e a investigação realizada neste âmbito, é possível lançar algumas pistas que visam uma boa utilização dos mesmos (utilização em tempo limitado, promotora da saúde e da atividade física) por parte dos jovens, procurando que possam ser realmente "ativos" e fomentem a atividade física regular.

Atendendo aos princípios de elaboração de videojogos com vista a ganhos de saúde através da promoção de atividade física, importa criar jogos que conjuguem elementos clássicos dos videojogos tradicionais com elementos do mundo/espaço real. Esta proposta resulta no que poderá ser denominado por RealVirtua Games. Os RealVirtua Games destinar-se-iam, principalmente, a jovens com idade a rondar os 13 anos (sem qualquer patologia de desenvolvimento), visto esta ser uma fase do desenvolvimento em que a autonomia ganha contornos de maior relevância. Nesta fase do processo de autonomia e da construção da identidade, estes jovens enfatizam o facto da "não constante" supervisão dos pais, embora os mesmos possam (e em nosso entender devam) também interagir e participar no jogo, sem uma atitude de "controlo" dos seus educandos.

Como o nome sugere, esta nova geração de videojogos teria duas dimensões:

1. Dimensão virtual. A partir das teorias explicitadas anteriormente, nomeadamente a Elaboration Likelihood Model (28), o jogo deverá ter uma história verosímil e agradável para cativar mais facilmente os jogadores (24). Para além disso, é importante que a história apresente um fio condutor, que seja dinâmica, credível e atrativa, de modo a promover a diversão e a concentração, bem como a fantasia e o entusiasmo, motivando intrinsecamente os jogadores (27). 
The game should be organized by increasing levels of difficulty of the tasks (as already happens usually in traditional videogames). Each of these levels must have short-term goals that the player must reach in order to get to the next step. The player receives constant feedback about their performance measured against these goals (and health gains), encouraging them to achieve the following tasks and, thus, favoring the development of skills (motor, cognitive or emotional) necessary to achieve these goals, enhancing their perception of selfefficacy. The importance of these aspects is justified in the social cognition theories of Bandura (29) and the self-determination theories of Deci and Ryan (13).

It is especially important that the game be operationalized through an AVATAR whose characteristics are customized by the player. The player should be given the privilege of choosing his/her own profile, in particular his/her physiognomic characteristics (height, hair color, eye color, etc.). These characteristics may be similar or not to the player himself, but that decision is up to him/ her. Thus, the player is projected in an AVATAR, which promotes identification with the character of the story of the videogame, enhancing greater immersion in the game's narrative and feeding/satisfying the need of "being in relation with".

Exergaming already involves the movement of the upper or lower torso. It is intended that the RealVirtua Games promote continuous movement throughout the body. All the movements performed by the AVATAR should mimic the result of a player's movements - walking, running, jumping, writing, fetching something, which implies the use of motion sensors in their hands and arms, their torso, hip, legs and feet.

In order to meet the basic psychological need to relate with others (13), and to promote appropriate psychosocial development, these games should also include (in addition to the motion sensors on the player) elements of participation in social groups, promoting cooperation and competition, as well as the support of the family and friendship network (and even teaching professionals). To this end, this new generation of video game should include dynamics between two or more AVATARS. The game's narrative should include objectives that are more easily attainable if collaborative work between AVATARS occurs.

2. Real dimension. This is probably the most innovative component in relation to classic videogames. The course of action will demand that the player (mediated by its AVATAR) undertake physical outdoor activities/ tasks, which will be presented as a personalized player difficulty-hierarchy list (from easiest to most difficult). The player could then chose the task/activity that is more accessible to themselves or more motivating,
O jogo deverá estar organizado por níveis crescentes de dificuldade das tarefas (tal como já acontece, habitualmente, nos videojogos tradicionais). Cada um desses níveis deverá ter objetivos de curto-prazo que o jogador deverá atingir para chegar à etapa seguinte. $\mathrm{O}$ jogador receberia feedback constante acerca do seu desempenho relativamente a estes objetivos (e dos ganhos de saúde), incentivando-o para a concretização das tarefas seguintes e, consequentemente, privilegiando o aprimorar das competências (motoras, cognitivas ou emocionais) necessárias para alcançar os referidos objetivos, reforçando a sua percepção de auto-eficácia. A importância destes aspetos encontram-se justificados nas teorias da cognição social de Bandura (29) e da auto-determinação de Deci e Ryan (13).

É especialmente relevante que o jogo seja operacionalizado através de um AVATAR cujas características sejam personalizadas pelo jogador. Deve ser dado ao jogador o privilégio de escolher o perfil do mesmo, nomeadamente as suas características fisionómicas (altura, cor de cabelo, cor dos olhos, entre outros). Estas características podem ser semelhantes ou não às do próprio jogador, cabendo ao mesmo decidir. Desta forma, o jogador projeta-se no AVATAR, o que promove a identificação com o personagem da história do videojogo, potenciando maior imersão na narrativa do jogo (e alimentando/satisfazendo a necessidade de "estar em relação com").

Os exergaming envolvem já a movimentação da parte superior ou inferior do tronco. Pretende-se que os RealVirtua Games incluam uma movimentação continuada de todo o corpo. Todos os movimentos realizados pelo AVATAR deverão resultar de uma mimetização do movimento do jogador - andar, correr, saltar, escrever, apanhar algo, etc. -, o que implica sensores de movimento não apenas das mãos e braços, mas também do tronco, anca, pernas e pés.

De forma a dar resposta à necessidade psicológica básica de se estar em relação com o outro (13), e no sentido de promover um desenvolvimento psicossocial adequado, é necessário que estes jogos incluam ainda (para além dos sensores de movimento do jogador) elementos de promoção de participação em grupos sociais, promovendo a cooperação e competição, bem como o suporte familiar e da rede de amizades (e mesmo de profissionais do ensino). Para tal, esta nova geração de videojogos deverá incluir dinâmicas entre dois ou mais AVATARS. A narrativa do jogo deverá, para tal, incluir objetivos que sejam mais facilmente ultrapassáveis se houver trabalho colaborativo entre AVATARS.

2. Dimensão Real. Esta é, provavelmente, a componente mais inovadora, relativamente aos videojogos clássicos. O desenrolar da ação deverá exigir ao jogador (mediado pelo seu AVATAR) tarefas/atividades físicas outdoor, que seriam apresentadas em forma de lista hierárquica de dificuldade (do mais fácil para o mais difícil) a personalizar pelo jogador. O jogador poderia assim escolher a tarefa/atividade que the fosse mais acessível ou que o motivasse mais, como por ex- 
such as hiking 1000 meters, cycling for fifteen minutes, among other possible activities.

Current technology enables us to monitor outdoor activities: through the player's mobile phone or remote console - fitted with GPS, context awareness, geo-location, accelerometer, among other applications - it is possible to see whether the proposed outside task has been successfully completed or not (a necessary condition in order to procede to the higher levels of the game).

\section{Advantages and Limitations of RealVirtua Games}

The component "real" in these kind of videogames contributes to reducing sedentary behavior. In addition to the various advantages of active videogames (exergames) it allows/promotes contact/interaction with the outside world. Furthermore, it would be possible to increase the level of difficulty of the tasks throughout the videogame in order to generate intrinsic motivation in young people, with the aim of promoting correct and healthy exercise. Likewise, it would be possible to include elements of nutrition education (e.g. tasks including purchase or confection of food).

The collective tasks also enables physical activity to be done in conjunction with a partner which, in addition to promoting social contact (and appropriate psychosocial development), is a factor in the promotion of energy expenditure habits (31).

These types of games could be also targeted at young people with disability, provided that they were adapted accordingly. The same could go for schools, rehabilitation centers, holiday camps, among other contexts.

Access to this type of videogame is obviously constrained by the cost associated with the technology (and devices) which involves for example: GPS, camera and video embedded in mobile devices (mobile phones or console remote control) and sensors that can detect the player's movements and locate the environments where the game is taking place (environment-awareness technology). Technological developments and market effects normally associated with this development tend to reduce the price of these products particularly if research proves that they are pleasurable and effective in promoting health gains.

\section{Conclusions}

The practice of regular physical activity is essential for health, but contemporary lifestyles and the organization of urban environments tend to discourage this activity, especially among the younger population. Exergaming is a proposal to reverse the infant-juvenile sedentary emplo, caminhadas de 1000 metros, o andar de bicicleta durante quinze minutos, entre outras atividades possíveis.

A tecnologia atual permite monitorizar as atividades exteriores: através do telemóvel do jogador ou do controlo remoto da consola - equipados com aplicações como GPS, geolocalização, context awareness, acelerómetros, etc. - é possível controlar se a tarefa proposta para o exterior teria sido resolvida com sucesso ou não (condição necessária para aceder a níveis seguintes da narrativa do jogo).

\section{Vantagens e Limites do RealVirtua Games}

A componente "real" deste tipo de videojogos contribuiria para a diminuição de comportamentos sedentários, pois além de incluir as várias vantagens dos videojogos ativos (exergames), permite/promove contacto/interação com o exterior. Para além disto, seria possível propor, ao longo do videojogo, tarefas diversificadas com níveis de dificuldade crescente, geradoras de motivação intrínseca nos jovens, com o objetivo de ensinar a praticar exercício físico de forma correta e saudável. Da mesma forma, seria possível incluir elementos de educação alimentar (por exemplo, incluindo tarefas orientadas de compra de alimentos ou de confecção dos mesmos). $\mathrm{O}$ facto de estes videojogos apostarem em tarefas coletivas permite ainda que a atividade física seja feita em conjunto com pares o que, para além de promover o contacto social (e respetivo desenvolvimento psicossocial), é um fator de promoção de hábitos de dispêndio energético (31).

Estes tipos de jogos poderiam também ser dirigidos a jovens com algum tipo de problemas, de natureza motora e/ou cognitiva, desde que com as devidas adaptações. O mesmo poderá acontecer em escolas, centros de reabilitação, campos de férias, entre outros contextos.

O acesso a este tipo de videojogo está obviamente condicionada pelo custo associado à tecnologia (e dispositivos) que implica: GPS, câmara fotográfica e de vídeo incorporada em dispositivos móveis (telemóveis ou comandos da consola), sensores que permitam detetar os movimentos do jogador, bem como localizar os ambientes em que se encontra (tecnologia environment-awareness), entre outros. Com o desenvolvimento tecnológico e efeitos de mercado normalmente associados a este desenvolvimento, o preço destes equipamentos tenderão no entanto a diminuir. Em especial se a investigação associada aos mesmos comprovar a sua efetividade em temos do efeito combinado do prazer proporcionado e dos ganhos de saúde.

\section{Conclusões}

A prática da atividade física regular é essencial para a saúde, embora, atualmente, os estilos de vida e a organização dos ambientes urbanos tenda a desencorajar esta atividade, nomeadamente entre as populações mais jovens. Os exergaming resultam numa proposta 
lifestyle, although it does not promote real contact with the outside world, or replace the type of physical activity which most effectively promotes health gains.

This article proposes elements of construction/development of videogames, based on some of the most recent models of behavioral change, where virtual and real complement each other to promote motor and psychosocial development, as well as physical activity habits. Taken that the playing of videogames is widespread among children and young people, it is essential that these people derive health benefits from this activity: the game appears on the screen, but promotes activities "on the street", in contact with the outside world. If it is becoming more difficult to draw young people away from the screens, it is essential that they can learn something from the game in addition to having fun, and develop relevant skills in various areas such as health, physical and mental fields.

\section{Conflict of Interest}

The authors declare that there is no financial or personal relationship that can be understood as representing a potential conflict of interest. para inverter o sedentarismo infanto-juvenil, embora não possibilitem um verdadeiro contacto com o mundo exterior, nem substituam totalmente a atividade física adequada a ganhos de saúde.

Neste artigo são propostos elementos de construção/desenvolvimento de videojogos, baseados em alguns dos modelos de mudança comportamental mais recentes, em que o virtual e o real se complementam de forma a promover desenvolvimento motor e psicossocial, bem como hábitos de atividade física. Sendo os videojogos uma prática generalizada entre crianças e jovens, é fundamental que estas populações retirem benefícios de saúde dos mesmos, mantendo o jogo no ecrã, mas fomentando atividades "na rua", em contacto com o mundo exterior. Se cada vez se torna mais difícil tirar os jovens da frente dos ecrãs, é fundamental que, para além da diversão, possam aprender algo com o jogo e que desenvolvam competências relevantes em vários domínios de saúde, física e mental.

\section{Conflito de interesses}

Os autores declaram que não há nenhuma relação financeira ou pessoal, que pode ser entendida como representando um potencial conflito de interesses. 


\section{References / Referências}

1. Jago R, Baranowski T, Watson K, Bachman C, Baranowski JC, Thompson D, et al. Development of new physical activity and sedentary behavior change self-efficacy questionnaires using item response modeling. Int. J. Behav. Nutr. Phys. Act. 2009;6:20.

2. Maddison R, Mhurchu CN, Jull A, Jiang Y, Prapavessis H, Rodgers A. Energy Expended Playing Video Console Games : An Opportunity to Increase Children 's Physical Activity? Pediatr. Exerc. Sci. 2007;19(6):334-43.

3. Mark R, Rhodes RE, Warburton DER, Bredin SSD. Interactive Video Games and Physical Activity: A Review of the Literature and Future Directions. Heal. Fiteness J. Canada. 2008;1(1):14-24.

4. Stamatakis E, Coombs N, Jago R, Gama A, Mourão I, Nogueira $\mathrm{H}$, et al. Associations between indicators of screen time and adiposity indices in Portuguese children. Prev. Med. (Baltim). 2013;56(5):299-303.

5. Pereira CA, Ramos A, Pereira B. Videojogos e práticas desportivas Video games and sport practice. Videojogos. 2009;1(1):1-10.

6. Periodicidade GM. Consolas e Videojogos. Marktest. 2006. p. 144-57.

7. Miranda A, Neves M, Tavares A, Santos O, Galvão-Teles A. Obesidade e tempo de exposição a actividades sedentárias, em adolescentes Portugueses, dos 11 aos 15 anos. Rev. Port. Cir. 2011;Supplement:58-9.

8. Rey-López JP, Vicente-Rodríguez G, Biosca M, Moreno L a. Sedentary behaviour and obesity development in children and adolescents. Nutr. Metab. Cardiovasc. Dis. 2008;18(3):242-51.

9. Vandewater E a, Shim M, Caplovitz AG. Linking obesity and activity level with children's television and video game use. J. Adolesc. 2004:27(1):71-85.

10. Haddock BL, Siegel SR, Wilkin LD. Energy Expenditure of Middle School Children While Playing Wii Sports Games. Californian J. Health Promot. 2010;8(1):32-9.

11. Do Carmo I, Dos Santos O, Camolas J, Vieira J, Carreira M, Medina L, et al. Overweight and obesity in Portugal: national prevalence in 2003-2005. Obes. Rev. 2008;9(1):11-9.
12. Ridgers ND, Mckinney J, Stratton G, Graves L. Comparing the Physiological Cost of Step-Powered Video Gaming, Sedentary Video Gaming, and Self-Paced Ambulatory Activity in University Students. Arch. Exerc. Heal. Dis. 2011;2(1):81-8.

13. Ryan RM, Deci EL. Self-determination theory and the facilitation of intrinsic motivation, social development, and well-being. Am. Psychol. 2000;55(1):68-78.

14. Biddiss E, Irwin J. Active Video Games to Promote Physical Activity in Children and Youth. Arch. Pediatr. Adolesc. Med. 2010;164(7):664-72.

15. Bushman BJ, Anderson $\mathrm{C}$ a. Violent Video Games and Hostile Expectations: A Test of the General Aggression Model. Personal. Soc. Psychol. Bull. 2002;28(12):1679-86.

16. Uhlmann E, Swanson J. Exposure to violent video games increases automatic aggressiveness. J. Adolesc. 2004;27(1):41-52.

17. Ferguson CJ. The good, the bad and the ugly: a meta-analytic review of positive and negative effects of violent video games. Psychiatr. Q. 2007;78(4):309-16.

18. Gentile D A, Lynch PJ, Linder JR, Walsh D a. The effects of violent video game habits on adolescent hostility, aggressive behaviors, and school performance. J. Adolesc. 2004;27(1):5-22.

19. Latner JD, Rosewall JK, Simmonds MB. Childhood obesity stigma: association with television, videogame, and magazine exposure. Body Image [Internet]. 2007;4(2):14755.

20. Gee JP. What video games have to teach us about learning and literacy. Comput. Entertain. 2003;1(1):20.

21. Baranowski T, Baranowski J, Thompson D, Buday R, Jago R, Griffith MJ, et al. Video game play, child diet, and physical activity behavior change a randomized clinical trial. Am. J. Prev. Med. 2011;40(1):33-8.

22. Kato, P.M. \& Beale IL. Factors affecting acceptability to young cancer patients of a psychoeducational video game about cancer. J. Pediatr. Oncol. Nurs. 2006;23(5):269-75.
23. Levac D, Pierrynowski MR, Canestraro M, Gurr L, Leonard L, Neeley C. Exploring children's movement characteristics during virtual reality video game play. Hum. Mov. Sci. 2010;29(6):1023-38.

24. Thompson D, Baranowski T, Buday R, Baranowski J, Thompson V, Jago R, et al. Serious Video Games for Health How Behavioral Science Guided the Development of a Serious Video Game. Simul. Gaming. 2008;41(4):587-606.

25. Epstein LH, Roemmich JN, Robinson JL, Paluch R a, Winiewicz DD, Fuerch JH, et al. A randomized trial of the effects of reducing television viewing and computer use on body mass index in young children. Arch. Pediatr. Adolesc. Med. 2008;162(3):239-45.

26. Radon K, Fürbeck B, Thomas S, Siegfried W, Nowak D, von Kries R. Feasibility of activity-promoting video games among obese adolescents and young adults in a clinical setting. J. Sci. Med. Sport. Sports Medicine Australia; 2011;14(1):42-5.

27. Baranowski T, Buday R, Thompson D, Baranowski J. Playing for Real: Video Games and Stories for Health-Related Behavior Change. Am. J. Prev. Med. 2008;34(1):74-82.

28. R. Petty \& J. Cacioppo. The Elaboration Likelihood Model of Persuasion. Adv. Exp. Soc. Psychol. 1986;19:123-62.

29. Bandura A. Social Foundations of Thought and action: a social cognitive theory. 1986.

30. Hall PA, Fong GT. Temporal self-regulation theory: A model for individual health behavior. Health Psychol. Rev.;1(1):6-52.

31. Lally P, Gardner B. Promoting habit formation. Health Psychol. Rev. 2011;1(22):1-22. 